\title{
East Greenland Caledonides: stratigraphy, structure and geochronology
}

Edited by

A.K. Higgins and Feiko Kalsbeek

GEOLOGICAL SURVEY OF DENMARK AND GREENLAND MINISTRY OF THE ENVIRONMENT 


\section{Geological Survey of Denmark and Greenland Bulletin 6}

\section{Keywords}

Caledonides, East Greenland, geochronology, stratigraphy, structure.

\section{Cover}

West-dipping white and rusty brown quartzites of the Lower Cambrian Slottet Formation, at Slottet in the Eleonore Sø foreland window, resting unconformably on dark clastic sediments of the Palaeoproterozoic Eleonore $\$ \varnothing$ complex. The summit of Slottet (1933 $\mathrm{m}$ high) is $600 \mathrm{~m}$ above the glacier surface.

Chief editor of this series: Adam A. Garde

Scientific editors of this volume: A.K. Higgins and Feiko Kalsbeek

Editorial secretaries: Esben W. Glendal and Birgit Eriksen

Critical readers: Arild Andresen (Norway), Brian Chadwick (UK), Lars Clemmensen (Denmark), Clark R.L. Friend (UK), David G. Gee (Sweden), John S. Peel (Sweden), John E. Repetski (USA), Minik Rosing (Denmark), Rob Strachan (UK) and Martin Whitehouse (Sweden)

Illustrations: Helle Zetterwall

Digital photographic work: Benny M. Schark and Jakob Lautrup Graphic production: Knud Gr@phic Consult, Odense, Denmark Printers: Schultz Grafisk, Albertslund, Denmark

Manuscripts submitted: 10 November 2003

Final versions approved: 9 June - 14 September 2004

Printed: 30 December 2004

ISBN 87-7871-148-7

\section{Geological Survey of Denmark and Greenland Bulletin}

The series Geological Survey of Denmark and Greenland Bulletin replaces Geology of Denmark Survey Bulletin and Geology of Greenland Survey Bulletin.

\section{Citation of the name of this series}

It is recommended that the name of this series is cited in full, viz. Geological Survey of Denmark and Greenland Bulletin.

If abbreviation of this volume is necessary, the following form is suggested: Geol. Surv. Den. Green. Bull. 6, 93 pp.

\section{Available from}

Geological Survey of Denmark and Greenland (GEUS)

Øster Voldgade 10, DK-1350 Copenhagen K, Denmark

Phone: +45 381420 00, fax: +45 381420 50, e-mail: geus@geus.dk

or

Geografforlaget ApS

Rugårdsvej 55, DK-5000 Odense C, Denmark

Phone: +45634416 83, fax: +45634416 97, e-mail: go@geografforlaget.dk

\section{(c) Danmarks og Grønlands Geologiske Undersøgelse (GEUS), 2004}




\section{Contents}

Preface

A.K. Higgins

Lower Palaeozoic stratigraphy of the East Greenland Caledonides

M.P. Smith, J.A. Rasmussen, S. Robertson, A.K. Higgins and A.G. Leslie

The Neoproterozoic Rivieradal Group of Kronprins Christian Land, eastern North Greenland

M.P. Smith, A.K. Higgins, N.J. Soper and M. Sønderholm . . . . . . . . . . . . . . . . . . .

The Caledonian thin-skinned thrust belt of Kronprins Christian Land, eastern North Greenland

A.K. Higgins, N.J. Soper, M.P. Smith and J.A. Rasmussen . . . . . . . . . . . . . . . . . . . .

Palaeoproterozoic age of a basement gneiss complex in the Charcot Land tectonic window, East Greenland Caledonides

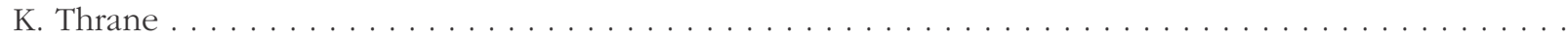

Reconnaissance $\mathrm{Pb}-\mathrm{Pb}$ dating of single mineral phases by the step-leaching method: results from the Caledonides of East Greenland

K. Thrane

The Eleonore Sø and Målebjerg foreland windows, East Greenland Caledonides, and the demise of the 'stockwerke' concept

A.K. Higgins and A.G. Leslie 


\section{Preface}

The East Greenland Caledonides extend from $70^{\circ}$ to $81^{\circ} 30^{\prime} \mathrm{N}$, and have been the subject of a series of regional mapping programmes between 1968 and 1998. The entire orogen is now covered by five published 1:500 000 geological map sheets. The six papers in this bulletin concern a variety of topics relating mainly to Kronprins Christian Land $\left(79^{\circ}-81^{\circ} 30^{\prime} \mathrm{N}\right)$ and the Kong Oscar Fjord region $\left(72^{\circ}-75^{\circ} \mathrm{N}\right)$.

The paper by Smith et al. on Lower Palaeozoic stratigraphy proposes amendments to several stratigraphical units that occur in Kronprins Christian Land and nearby Lambert Land. In the Kong Oscar Fjord region, two new formations are defined for quartzite and limestone/dolostone units that crop out in foreland windows, and the Lower Palaeozoic succession of the fjord region of East Greenland is formally placed in the Kong Oscar Fjord Group. The second paper by Smith et al. describes and formally defines the Neoproterozoic Rivieradal Group of Kronprins Christian Land. The paper by Higgins et al. analyses the thin- skinned fold-and-thrust belt that marks the transition between foreland and orogen in Kronprins Christian Land, and presents a balanced cross-section restoration.

The two geochronological papers by Thrane report the results of ion microprobe zircon analyses from orthogneisses in the Charcot Land window $\left(72^{\circ} \mathrm{N}\right)$, and results of reconnaissance $\mathrm{Pb}-\mathrm{Pb}$ dating by the stepleaching method.

The final paper by Higgins \& Leslie reviews the history of geological research in the Eleonore $\$ \varnothing$ and Målebjerg areas of the Kong Oscar Fjord region $\left(72^{\circ}\right.$ $75^{\circ} \mathrm{N}$ ). Recognition that the two areas are part of the Caledonian foreland implies that the two thrust sheets structurally overlying the Eleonore $\$ \varnothing$ and Målebjerg windows have large displacements ( $100 \mathrm{~km}$ each), and that the 'stockwerke' concept of the orogen that focused on in situ vertical movements can finally be laid to rest. 